\title{
慢性関節リウマチ患者の顎関節症状に対する顎運動療法の効果
}

\author{
朝比奈たまき・水谷英樹・杉村泰郎 \\ 兼子隆次・千賀勝広・上田実
}

\section{Clinical Effect of Physiotherapy for Temporomandibular Disorders of Patients with Rheumatoid Arthritis}

\author{
Tamaki Asahina $\cdot$ Hideki Mizutani $\cdot$ Yasuo Sugimura \\ Ryuji KaneKo $\cdot$ Katsuhiro Senga $\cdot$ Minoru Ueda
}

\begin{abstract}
Rheumatoid arthritis (RA) is a chronic inflammatory disease with immunologic abnormalities. Although the temporomandibular joint (TMJ) can be involved, early changes of the TMJ affected by RA are unclear, and the treatment for temporomandibular disorders (TMD) in patients with RA is not established yet. Physiotherapy is effective for general joints with RA but its effect for RA of the TMJ is unknown. The clinical effects of physiotherapy for TMD in RA patients was investigated. Five patients with RA visited our department with complaints of the TMD. Physiotherapy, including exercises of TMJ movement and mastication training were stasted, bilaterally and simultaneously. Clinical findings showed an increase in maximal interincisal distance with no pain after therapy in 4 patients. No patient had anterior open bite or TMJ ankylosis in the follow-up period (2.5 to 5.3 years). These results suggest that physiotherapy is also effective for the TMD in RA patients.
\end{abstract}

Key words: temporomandibular joint（顎関節）, rheumatoid arthritis（慢性関節リウマチ）， physiotherapy（顎運動療法）

\section{緒}

\section{言}

慢性関節リウマチ $(\mathrm{RA})$ は, 関節およびその周囲組 織に炎症性変化をきたす免疫学的異常を伴う慢性炎症 性疾患である。顎関節においては, 顎関節リウマチと され，顎関節の炎症性疾患に分類されている ${ }^{1)}$. 顎関 節破壊進行例 ${ }^{2)}$ や顎関節強直症を併発した重度進行 症例 ${ }^{3)}$ での治療についての報告はみられるが, 軽症あ るいは中等度症例での治療法は明らかではない．

今回われわれは, 顎関節症状を主訴として当科を受 診したRA 患者に対して, 積極的な顎運動療法を施行 し，長期経過観察を行ったので報告する.

\section{1. 対象症例}

1992年から 1996 年の 5 年間に

名古屋大学医学部口腔外科学講座

（主任：上田 実教授)

Department of Oral Surgery, Nagoya University School of Medicine (Chief: Prof. Minoru Ueda)

受付日: 平成 9 年 8 月 7 日
顎関節症状を主訴として受診した $\mathrm{RA}$ 患者中, 前歯開咬を認めない顎関節りウマチ患者 5 症例とした。全例女性で, 初診時平均年齢は, 54.4歳 （34〜70歳）であった. 全例当院整形外科にて通院加療 を受けており，RA 平均罹病期間は 11 年 $(2 \sim 24$ 年 $)$ であった.いずれも Steinbrocker らの機能障害度分 類 ${ }^{4)}$ は class II であった. また, すべての症例で整形 外科より消炎鎮痛剤の処方を受けていた。当科初診時 臨床所見は平均開口距離 $30.6 \mathrm{~mm} \quad(20 \sim 45 \mathrm{~mm})$, 開口 時痛のみを訴える症例が 2 症例; 開口障害のみは 1 症 例, 開口時痛・開口障害を訴える症例が 2 症例であっ た. 顎関節雑音は 3 症例に認められた。初診時血液検 查所見は RA テスト $(2+)$ が 2 症例, $(1+)$ が 1 症 例, (一) が 2 症例であった（表 1 ).

顎関節矢状断層撮影法を用いた単純 X 線検査では, 下顎頭の骨形態変化がすべての症例に認められた。ま た, 磁気共鳴画像 (MRI) 撮像を 4 症例について行い, 復位を伴う関節円板前方転位が 2 症例, 復位のない関 節円板前方転位は 1 症例であった. 形態変化は 4 症例 に認められた（表 2 ). 
表 1 初診時臨床所見および血液検査所見

\begin{tabular}{|c|c|c|c|c|c|c|c|c|c|c|}
\hline $\begin{array}{l}\text { 症例 } \\
\text { No. }\end{array}$ & 年齢 & 主 訴 & $\begin{array}{c}\text { 開口距離 } \\
(\mathrm{mm})\end{array}$ & 雑音 & $\begin{array}{l}\mathrm{RA} \text { 罹病 } \\
\text { 期間 (年) }\end{array}$ & $\begin{array}{l}\mathrm{RA} \\
\text { テスト }\end{array}$ & $\begin{array}{c}\mathrm{CRP} \\
(\mathrm{mg} / \mathrm{dl})\end{array}$ & $\begin{array}{c}\lg G \\
(\mathrm{mg} / \mathrm{dl})\end{array}$ & $\underset{(\mathrm{mg} / \mathrm{dl})}{\operatorname{lgM}}$ & $\begin{array}{l}\lg \mathrm{A} \\
(\mathrm{mg} / \mathrm{dl})\end{array}$ \\
\hline 1 & 34 & rt.開口時痛 & 45 & rt.crepitus & 9 & $2^{+}$ & 3.9 & 1837 & 344 & 332 \\
\hline 2 & 54 & 開口障害 & 30 & It.çrepitus & 24 & - & 0.1 & 1409 & 80 & I \\
\hline 3 & 55 & lt.開口時痛 & 28 & rt.click & 11 & $1^{+}$ & 2.7 & 1395 & 102 & 225 \\
\hline 4 & 59 & $\begin{array}{l}\text { rt. 開口時痛 } \\
\text { 開口障害 }\end{array}$ & 30 & - & 2 & $2^{+}$ & 0.9 & 1379 & 342 & 397 \\
\hline 5 & 70 & $\begin{array}{l}\text { lt. 開口時痛 } \\
\text { 開口障害 }\end{array}$ & 20 & - & 9 & - & 0.1 & 1223 & 115 & 396 \\
\hline
\end{tabular}

表 2 下顎頭 ・関節結節の骨変形と関節円板の MRI 所見

\begin{tabular}{|c|c|c|c|c|c|}
\hline 症例No. & & 下顎 頭 & 関節結節 & 関節円板の位置 & 関節円板の形態 \\
\hline \multirow[t]{2}{*}{1} & rt. & $\begin{array}{l}\text { concavity } \\
\text { flattening }\end{array}$ & - & 前方転位復位あり & even thickness \\
\hline & lt. & eburnation & - & 前方転位復位あり & biconcave \\
\hline \multirow{2}{*}{2} & rt. & - & - & 正常 & biconcave \\
\hline & lt. & erosion & erosion & 正 常 & even thickness \\
\hline \multirow{2}{*}{3} & rt. & $\begin{array}{l}\text { flattenig } \\
\text { erosion }\end{array}$ & deformity & I & l \\
\hline & lt. & $\begin{array}{l}\text { flattenig } \\
\text { eburnation }\end{array}$ & eburnation & I & I \\
\hline \multirow{2}{*}{4} & rt. & erosion & - & 前方転位復位なし & folding \\
\hline & lt. & - & - & 正常 & biconcave \\
\hline \multirow[b]{2}{*}{5} & rt. & erosion & - & 正 & biconcave \\
\hline & lt. & $\begin{array}{l}\text { flattenig } \\
\text { erosion }\end{array}$ & deformity & 前方転位復位あり & folding \\
\hline
\end{tabular}

表 3 顎運動療法後の変化

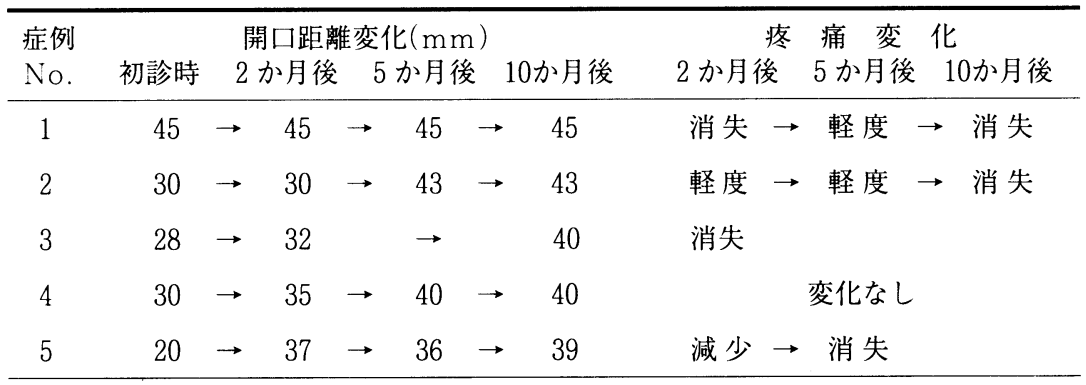

\section{2. 顎運動療法および評価法}

自宅での顎運動訓練として, 開口・前方・側方運動 を約 $5 \sim 10$ 分間， 1 日に起床時·毎食後·入浴時 · 就
寝前に行うよう指導した 開口運動は, 疼痛の自制可 内でまっすぐに，また下顎 をやや前方に出すような開 口を, 前方・側方運動は軽 く開口した状態で両手を㚘 部に沿わせて補助する形で 左右均等に行うよう指示し た。同時に咬笳部の筋マッ サージも行うよう指導した。 また, 食事は両側同時咀嚼 を行うよう指導した. 来院 頻度は, 初診から 2 か月ま では 2 週に 1 度, その後 1 年間は 1 か月に 1 度, その 後は2〜3か月に1度とした。 来院時にはアンケート記載, 開口距離・下顎運動の計測, マニピュレーションテクニッ クにより積極的に下顎頭部 の毫引を行った。評価は, 開口距離・疼痛の変化, ア ンケートによる生活支障度 指数を参考に当科の基準で 行った ${ }^{5}$.

\section{結 \\ 果}

この療法による平均治療 期間は 3.9 年 $(2.5 \sim 5.3$ 年) であった. 治療により「改 善あり」と判断されたもの は, 治療開始 2 か月後で 3 症例, 10か月後には全例で 「改善あり」となった. 経過 観察中, 全例 $38 \mathrm{~mm}$ 以上の 開口距離が維持され，開口 障害による生活支障度は改 善されていた。また, 治療 2 か月で初診時に疼痛を認め ていた 4 症例中 3 症例に改 善がみられ，10か月後では 疼痛, 開口障害共に認めら れない症例は 4 症例であっ た.しかし, 開口時雑音は 変化なく, 開口距離増加に 伴って, 下顎頭運動域全域 に及ぶ crepitus 様の雑音 が触知された. 全症例, 治療期間中に咬合の変化はな く, 前歯部開咬も認められなかった（表 3 ).

また, 顎運動療法前の MRI 所見と 1 年間の運動療 


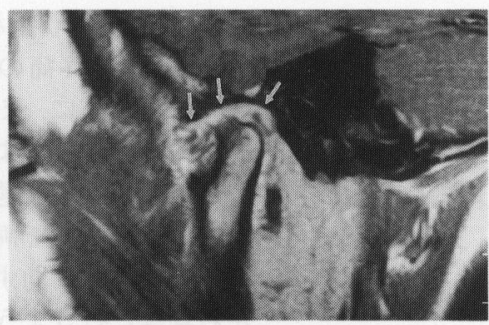

写真 1 ガドリニウム造影 MR 像 滑膜の増殖を疑わせる高信号が上 関節腔にみとめられる.（

法後の MRI 所見の比較を行った結果，症例 1 では開 口に伴う関節円板の動きはあるものの，断裂を疑わせ る所見や下頡頭の内側極の低信号域の拡大などが新た に観察された.また,ガドリニウム造影で上関節腔に 高信号が認められ，滑膜の増殖を疑わせる所見が得ら れた (写真 1 ). その他の症例では前後での変化は見ら れなかった。

\section{考察}

顎関節リウマチについての発現頻度や診断基準は多 数報告されているが6 9)，両側性に顎関節破壊進行が 認められる症例以外は, 治療法に関しての報告はない.

他関節 RA では機能障害が発症直後から急速に進 行することから, 発症早期からの予防的リハビリテー ションが重要とされている10). RA における運動療法 の目的は, 疼痛の軽減, 関節可動域の維持 · 拡大, 筋 力の維持 - 増大, 筋萎縮の予防, 拘縮 - 変形の予防 進行阻止, 血行の改善, 姿勢の矯正, 日常生活動作の 改善と向上にある. 関節可動域障害の原因として有痛 性拘縮, 廃用性拘縮, 骨関節破壊に伴う異常可動が挙 げられている. 整形外科領域では，これら拘縮を予防 するために様々な運動訓練を行っている ${ }^{4)}$. しかし， 顎関節に対しての積極的な訓練指導はされておらず, またその効果も不明である.

今回, 顎関節リウマチ症状としては比較的軽症症例 において, 運動療法が症状の改善および病態の進行防 止に効果があるか否かを検討した. その結果, 初診時 $30 \mathrm{~mm}$ 以下の開口距離であった 4 症例に開口障害の改 善が認められ，また， 4 症例に疼痛の消失が得られ， 顎運動療法が主訴の改善に有効であることが示唆され た. 顎運動を積極的に行うことで，関節周囲組織の伸 展や循環改善, 炎症物質や代謝産物の貯留の減少が得 られ, 開口距離の増加や疼痛の減少につながったと推 察できる.また, 長期経過観察では, 関節痛減少によ る機能改善が咀嚼筋群の筋力低下防止と関節内拘縮予
防に効果的に作用し，長期にわたって良好な顎運動が 維持されることが示唆された。

しかし, 運動療法前後の MRI 所見の比較では, 下 顎頭, 円板に変形あるいは変性の進行を伺わせる症例 があり,さらなる経過観察が必要と思われた。

今後, RA 患者に対して, 整形外科領域で指導され ているリウマチ体操に頇関節のリハビリテーションと しての顎運動療法を加え, 早期の顎関節症状に対応し ていく必要性が示唆された.

\section{結語}

顎関節症状を主訴として当科を受診した RA 患者 中, 開咬を認めない顎関節リウマチ患者 5 症例を対象 に顎運動療法を行った. 4 症例に開口距離の増加，4 症例に疼痛の消失が得られ，また長期経過観察期間を 通じて症状の悪化がみられなかったことから，RA 患 者に対する顎運動療法の積極的導入が有用であること が示唆された。

\section{文献}

1）日本顎関節学会：顎関節疾患および顎関節症の 分類 (改訂案), 1996.

2) 杉本瑞生, 東 文造, 他 : 上位頸椎病変と顎関 節破壊により閉塞性睡眠時無呼吸症候群を発症 した慢性関節リウマチに対する治療経験。臨整 形 29: 939-943 1994.

3）今村英夫, 久保田英朗, 他 : 顎関節強直症を併 発した慢性関節リウマチの 1 例. 日顎誌 5: 4654721993.

4）石原義恕, 勝部定信, 共編：リウマチテキストー 疾患の理解とケアの実際一。第 1 版, 南江堂, 東京, 1992, 37, 87-97.

5）瀬古和秀, 水谷英樹, 他 : 両側性非復位性関節 円板前方転位症例の臨床的検討. 日口外誌 42: 164-169 1996.

6）水谷英樹, 篠塚 襄, 他 : 慢性関節リウマチと 顎関節一その病変の推移と X 線所見一。日口 外誌 31: 2421-2431 1985.

7) CelikerR., Gokce-Kutsal Y., et al: Temporomandibular joint involvement in rheumatoid arthritis Relationship with disease activity. Scand J Rheumatol 24: 22-25 1995.

8）土川幸三, 加藤譲治, 他 : 顎関節リウマチの診 断基準作成のための検討. 日口外誌 37: 102410321991.

9）田中潤一, 伊藤要希, 他：慢性関節リウマチ患 者における靧関節異常とその対策. 口科誌 45 : 497-503 1996.

10）大山峰生, 木野義武, 他 : 慢性関節リウマチ手 における機能評価および運動プログラム，OT ジャーナル 30: 532-542 1996. 